\title{
Evidence of an Marine Isotope Stage 3 transgression at the Baixada Santista, south-eastern Brazilian coast
}

\author{
Evidência de uma transgressão na Baixada \\ Santista durante o Estágio Isotópico 3
}

\begin{abstract}
André da Silva Salvaterra ${ }^{1}$, Rosangela Felício dos Santos ${ }^{1}$, Alexandre Barbosa Salaroli $^{1}$, Rubens Cesar Lopes Figueira ${ }^{1}$, Michel Michaelovitch de Mahiques ${ }^{1,2 *}$
\end{abstract}

\begin{abstract}
In this paper, we present new evidence regarding a Marine Isotope Stage 3 (MIS3) transgression on the south-eastern Brazilian coast (Baixada Santista coastal plain). Data collected from a Standard Penetration Test (SPT) drilling reveal the occurrence of myxohaline sediments between cal BP 45,000 and 41,000. A deeper sequence, which shows a clear transition from terrestrial to a myxohaline environment, was associated with MIS5e. Organic and inorganic proxies have been used to recognize the variations on the terrestrial/myxohaline/marine deposits, as well as to infer about climate and energy of the depositional environment. Environmental change, which could correspond to a sea-level peak or the occurrence of drier conditions, was recognized between 43,000 and $42,000 \mathrm{cal}$ BP. The results reinforce the need for future works on MIS3 variability on the South American Atlantic coast.
\end{abstract}

KEYWORDS: Marine Isotope Stage 3; Late Pleistocene; sea-level.
RESUMO: Neste artigo, apresentamos novas evidências sobre a transgressáo ocorrida Estágio Isotópico 3 (MIS3) na costa do sudeste do Brasil (Baixada Santista). Dados coletados por meio de um ensaio de penetração em solo (SPT) revelam a ocorrência de sedimentos mixohalinos entre 45.000 e 41.000 anos a.P. Uma sequência mais profunda, que mostra clara transiçấo de ambiente continental para um mixohalino, foi associada ao Estágio Isotópico 5e (MIS5e). Marcadores orgânicos e inorgânicos foram usados para reconhecer as variaçōes dos ambientes terrestre/mixohalino/marinho, bem como inferir sobre o clima e a energia do ambiente deposicional. Uma mudança ambiental, que poderia corresponder a um pico do nivel do mar ou à ocorrência de condiçôes mais secas, foi reconhecida entre 43.000 e 42.000 anos a.P. Os resultados reforçam a necessidade de futuros trabalhos sobre a variabilidade do MIS3 na costa atlântica sul-americana.

PALAVRAS-CHAVE: MIS3; Pleistoceno superior; nivel do mar.

\footnotetext{
${ }^{1}$ Instituto Oceanográfico, Universidade de São Paulo - USP, São Paulo (SP), Brazil. E-mails: salvaterra@usp.br, rosangela.santos@usp.br, alexandre.salaroli@usp.br, rfigueira@usp.br,mahiques@usp.br

${ }^{2}$ Instituto de Energia e Meio Ambiente, Universidade de São Paulo - USP, São Paulo (SP), Brazil. E-mail: mahiques@usp.br

*Corresponding author

Manuscript ID: 20170057. Received in: 04/19/2017. Approved in: 09/01/2017
} 


\section{INTRODUCTION}

The Marine Isotope Stage 3 (MIS3) corresponds to the time interval between 60 and $25 \mathrm{ka}$ (Siddall et al. 2008) and is marked by a series of abrupt oscillations, corresponding to in the form of warming periods (Chappell 2002, Van Meerbeeck et al. 2009). Estimates based on $\delta^{18} \mathrm{O}$ chronologies and U/Th dating of coral reefs indicate that during this time interval sea level oscillated between 80 and $30 \mathrm{~m}$ below present sea level (mbsl) (Chappell \& Shackleton 1986, Lambeck and Bard 2000, Chappell 2002, Pahnke et al. 2003, Rabineau et al. 2006). Short-term oscillations in time intervals between $6,000-7,000$ years followed by $10-15 \mathrm{~m}$ sealevel rise events, corresponding to Heinrich events, occurred in this time interval (Chappell 2002).

On the other side, there are several papers that report the occurrence of MIS3 highstands at levels considerably shallower than those ones reported by the traditional sea level curves (Cann et al. 1993, Murray-Wallace et al. 1993, Rodriguez et al. 2000, Murray-Wallace 2002, Hanebuth et al. 2006, Simms et al. 2009, Doğan et al. 2012).

In South America, other examples of MIS3 highstands have been described both in the Atlantic and Pacific coasts (Isla 1990, Isla \& Schnack 2016), but part of these data have been disproved by Schellmann and Radtke (1997), who compared radiocarbon data with Electron Spin Resonance (ESR) information. In the Brazilian coast, Silva et al. (2014) recognized a lagoonal environment, dated from 47,000 to $36,000 \mathrm{BP}$, in the Maricá coastal plain (state of Rio de Janeiro).

Additionally, a complete set of coherent (no age reversal) radiocarbon ages in both organic matter and foraminifera, ranging from 39,000 to about $24,000 \mathrm{BP}$, marks the transition of myxohaline to freshwater conditions in a shallow-water $(6 \mathrm{mbsl})$ deposit in the São Sebastião Channel (state of São Paulo) (Mahiques et al. 2011). Other unpublished (thesis) data, from the Paraná state, also report MIS3 high levels in the shelf and adjacent coastal plain (Souza 2005, Veiga 2005).

The main criticism of the papers dealing with MIS3 highstands is associated with the limitations of the radiocarbon as a geochronological tool. Indeed, a significant part of the MIS3 interval cannot be dated with confidence beyond cal BP 45,000, and contamination of older materials with young carbon can result in apparent MIS3 ages (Murray-Wallace et al. 1993, Yim 1999, Hanebuth et al. 2006). On the other hand, the introduction of the Accelerator Mass Spectrometry (AMS) technique to radiocarbon dating (Dorn et al. 1989) brought another perspective to the original chronology limitation of cal BP 30,000 years. Thus, it is possible that several Pleistocene samples dated in the original studies of the
Brazilian coast might need to be reviewed due to the possible occurrence of an MIS3 highstand.

In this paper we analyze a new set of sedimentological and geochemical data, coming from a drilling performed in the Baixada Santista coastal plain (southeast Brazil), with evidence of two transgressive events, one of them with evidence of an MIS3 transgression. Data will be compared with other evidence of an MIS3 sealevel rise, reported in the SW Atlantic as well as in other coastal areas.

\section{STUDY AREA}

The study site (Fig. 1) is located in the so-called Baixada Santista coastal plain, an area covered by Late Pleistocene / Holocene coastal and marine muddy to sandy deposits, originally associated with two main transgressive events: Cananeia (MIS 5e) and Santos (Mid-Holocene) (Suguio \& Martin 1978b).

Towards the continent the coastal plain is limited by the Serra do Mar mountain range, exhibiting a width, variable from a few to almost $20 \mathrm{~km}$. The Quaternary sediments are locally interrupted by Pre-Cambrian massifs, forming groups of hills that are aligned according to SW-NE (Almeida $\&$ Carneiro 1998).

According to Suguio and Martin (1978a), the Cananeia Transgression is associated with a sea level rise that reached about $8 \mathrm{~m}$ above present sea level (mapsl), while the Santos Transgression reached 4.5 mapsl. Aspects of the evolution of the deposits were studied by Suguio and Martin (1978a) and Coelho et al. (2010). Angulo et al. (2006) reviewed the Mid- to Late Holocene sea-level changes and defined an envelope in which the maximum sea-level of $5.6 \mathrm{cal} \mathrm{yr} \mathrm{BP}$ ranged from 2 to about 4 mapsl.

On the other hand, there is almost no information about the position of the sea-level of the eastern to southern Brazilian between the climatic optimum of the MIS5e and the early Holocene. Corrêa (1996) proposed a sealevel curve between the Last Glacial Maximum and the early Holocene, based on the position of abrasion terraces on the southern Brazilian continental shelf and comparing them with global sea-level curves. Vicalvi et al. (1978) recognized a paleo-lagoon at the Abrolhos Depression (Eastern Brazilian shelf), dating them at 10,600 yr BP (uncalibrated). Finally, Mahiques et al. (2011), presented four datings on different material from a beach-rock located at 13 mbsl São Sebastiáo (southeastern Brazil), which gave calibrated ages around 8,200 yr BP.

Suguio and Martin (1978a) provided an interpretative profile of sedimentary deposits in the area (Fig. 2), 
recognizing continental sediments, marine and sand dunes of Late Pleistocene age, transitional sediments and Holocene lagoonal deposits, in addition to modern alluvium deposits located at the base of the Serra do Mar range.

The lower terrains lead to the establishment of a complex of estuarine channels, bordered by mangrove vegetation. On the other side, the sandy deposits and a significant part of the hills are presently occupied by urban, industrial and port infrastructure, which makes the Baixada Santista one of the most developed areas of Brazil.

\section{METHODS}

In this paper, we analyzed a $58.45 \mathrm{~m}$ long Standard Penetration Test (SPT) drilling, located at the coordinates $23^{\circ} 57.2512^{\prime} \mathrm{S}$ and $46^{\circ} 24.6018^{\prime} \mathrm{W}$, at the altitude of $8 \mathrm{mbsl}$ (Fig. 1). From the SPT drilling, a cylinder of $15 \mathrm{~cm}$ was recovered at each 1 meter. Samples were then air-dried and kept in polyethylene vials until laboratory analysis.

Radiocarbon dating was performed on the organic fraction of sediment samples by the Accelerator Mass Spectrometry (AMS) at Beta Analytic Laboratories (Miami, United States). Calibrated ages have been calculated according to the SH13 Southern Hemisphere Calibration (Hogg et al. 2016).

Grain size was performed in a Malvern Mastersizer 2000 laser diffraction system. Approximately $4 \mathrm{~g}$ of dry sediment were leached with $\mathrm{H}_{2} \mathrm{O}_{2}$ until the complete removal of the organic matter. Finally, $20 \mathrm{~mL}$ of a solution of $25 \%$ sodium hexametaphosphate was added as a dispersant. Results were obtained in intervals of $1 / 4 \varphi$, and statistical parameters were calculated with the aid of the Gradistat macro (Blott \& Pye 2001).

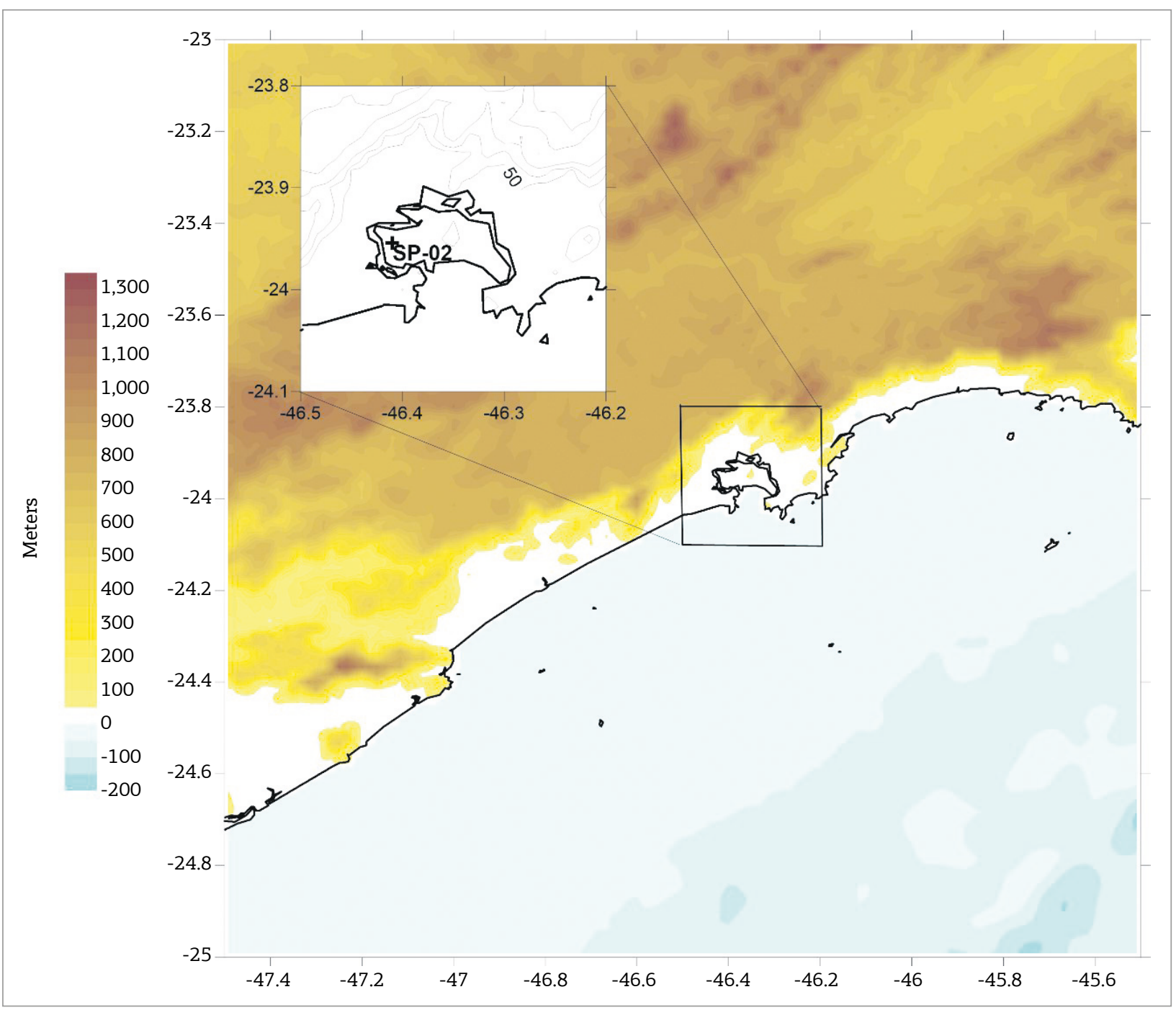

Figure 1. Hypsometric map of the central coast of the State of São Paulo and adjacent continental shelf (data source ETOPO1, NOAA 2016). In detail, the location of the drilling site. 
$\mathrm{CaCO} 3$ content was determined by the weight difference of the sediments before and after acidification with $10 \% \mathrm{HCl}$.

Organic Carbon $\left(\mathrm{C}_{\text {org }}\right)$ and total Nitrogen $\left(\mathrm{N}_{\text {tor }}\right)$, as well as the isotope ratios $\delta^{13} \mathrm{C}_{\mathrm{PDB}}$ and $\delta^{15} \mathrm{~N}_{\mathrm{AIR}}$, were determined by using a Finnigan Delta V Plus mass spectrometer coupled with a Costech Elemental Analyser. The IAEA 600 , USGS40, Leco ${ }^{\text {тм }}$ Soil and a secondary marine sediment standard from Ubatuba (SE Brazil) were used as reference materials.

Metals (Al, Ba, Ca, Fe, K, Mg, Sc, Sr, Ti, and V) were analyzed with a Varian 710 ICP-OES, following the procedures of total digestion established in the US Environmental Protection Agency 3052 Method. The methodology for metal determination is fully described in Mahiques et al. (2017). Metal/metal ratios in their logarithmic forms have been used to help the interpretation of the marine/terrestrial character, source rock and climate (Govin et al. 2012, Razik et al. 2015, Mahiques et al. 2017).

Values of $\mathrm{d}^{13} \mathrm{C}_{\mathrm{PDB}}$, N/C and $\ln (\mathrm{Ti} / \mathrm{Ca}$ ) (Govin et al. 2012), have been used to evaluate the marine versus terrestrial contribution. The values of $\ln (\mathrm{Fe} / \mathrm{K}$ ) (Govin et al. 2012) have been used as a proxy of weathering of source rocks. The values of $\ln (\mathrm{Ti} / \mathrm{Al})$ have been used as proxies of changes in energy of the environment (Govin et al. 2012, Chen et al. 2013).

For both inorganic and bulk organic contents, we present only the results that reached values higher than the Limit of Quantification (LQ), defined as five times the Limit of Detection (LD) for each parameter.

For grain size data, a Correspondence Factor Analysis, with the aid of the software Past version 3.15 (Hammer et al. 2001) was performed. For the metal content, an R-mode cluster analysis, using the Correlation matrix and Unweighted Pair Group Method with Arithmetic (UPGMA) clustering technique was used.
All of the altitude/depth results are reported in meters relative to the present sea level, and samples are named according to their position (i.e., sample -12 refers to a sample collected at $12 \mathrm{mbsl}$ ).

\section{RESULTS AND DISCUSSION}

All of the results are presented as Supplementary Material of this paper.

A field macroscopic description is presented in Figure 3A.

Concerning chronology, a sample, located at $40 \mathrm{mbsl}$, provided an age beyond the limit of the radiocarbon dating (MIS5e?). The $\delta^{13} \mathrm{C}_{\mathrm{PDB}}$ of this sample (-29.6\%o) indicates a terrestrial organic matter. Another sample, located at $19 \mathrm{mbsl}$, was dated at Cal BP 44,890 (2s: $45,580-44,200)$ (MIS3) and provided a $\delta^{13} \mathrm{C}_{\mathrm{PDB}}$ value of $-24.4 \%$, indicative of a mixture of marine and terrestrial organic matter. Finally, a third sample, collected at $7 \mathrm{mbsl}$, provided a cal age of 40,950 (2s: 41,530-40,300) (MIS3) and a $\delta^{13} \mathrm{C}_{\mathrm{PDB}}$ value of $-24.5 \%$, also indicative of mixed organic matter.

SPT values (Fig. 3B) vary significantly along the drilling. Higher values correspond to its base, which has been described as weathered rock. The lowest values of SPT correspond to the interval between 12 and $18 \mathrm{mbsl}$.

Values of mean diameter (Fig. 3C) are roughly correlated with values of SPT $(R=-0.26, p=0.04)$, with variations between $1.93 \varphi$ (medium sand) to $5.39 \varphi$ (medium silt). Sorting varies from very poor sorted, at the base, to well sorted, associated with fine and very fine sands (see Supplementary Material, Tab. 1).

The lack of an expected high correlation between Mean Diameter with SPT should be associated to the increasing compaction of the sediments, towards deeper strata.

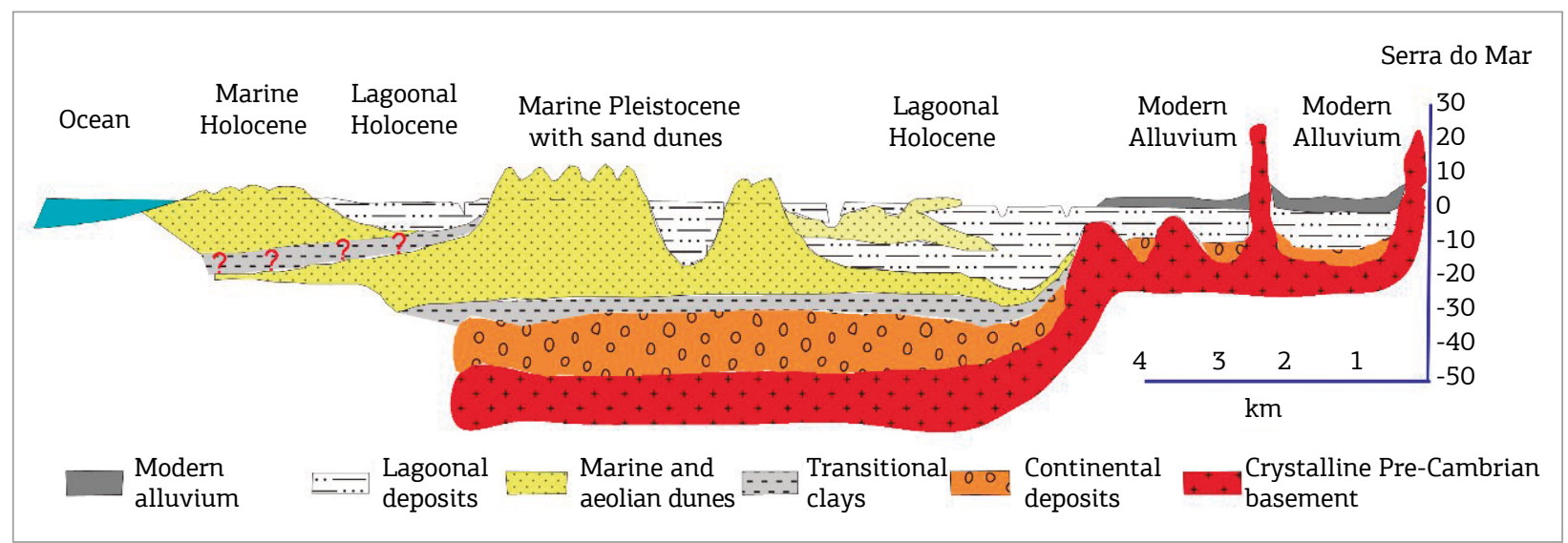

Figure 2. Schematic geological transect of the Baixada Santista coastal plain, with the main geological units. Adapted from Suguio and Martin (1978b). 
The $\mathrm{CaCO}_{3}$ contents are always low, varying from less than $0.5 \%$ to about $9.4 \%$. This parameter correlates significantly with both SPT $(\mathrm{R}=-0.49, \mathrm{p}=0.00)$ and Mean Diameter $(\mathrm{R}=0.76, \mathrm{p}=0.00)$.

The Correspondence Factor Analysis (Fig. 4) allowed recognizing four main types of grain size distributions. The first one is represented by a poorly sorted coarse to medium silt, platykurtic and positively skewed distribution, represented by sample -40 . It corresponds to the muddy sequences dated as MIS3 and beyond the limit of radiocarbon dating (MIS5e?).

The second group, represented by sample -3 , has a bimodal distribution. The main mode is centered at $3 \varphi$, with a leptokurtic symmetric distribution. The secondary mode is centered at $5.75 \varphi$ and shows a much lesser expression. It expresses the sandy sediments associated to the MIS3 muds.

The third group is expressed by sample 1 . It corresponds to a leptokurtic symmetric distribution, centered at $2 \varphi$, and represents the topmost sediments of the drilling.

Finally, the fourth group, expressed by sample -34, consists of a strongly asymmetric distribution, meso- to platykurtic, with the main mode at $1.75 \varphi$, and progressively small amounts of silts and clay. This group is mainly related with the sandy sediments associated with the MIS5e muds.

Concerning the proxies of sediment provenance and energy (Figs. 5A to 5F), there is a clear evidence of a terrestrial environment in samples -39 and -40 , both in organic (Figs. 5A and 5B) and inorganic (Fig. 5C) parameters.
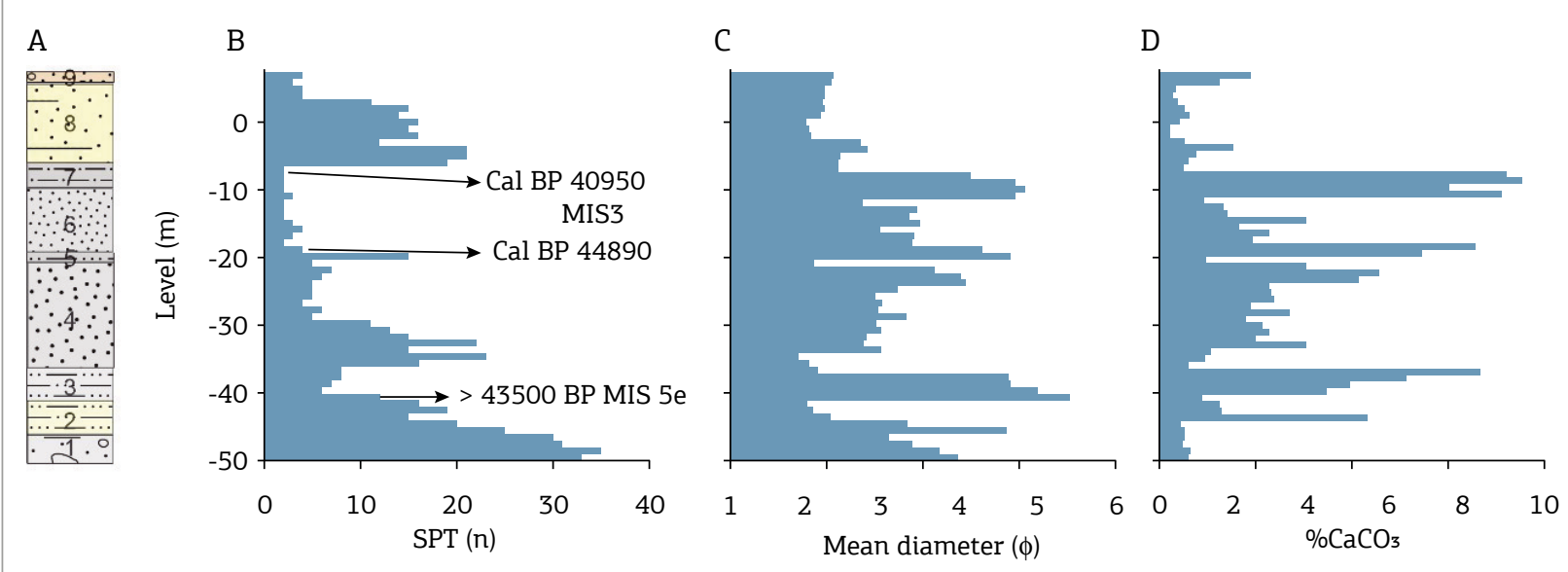

Figure 3. (A) General macroscopic description: (1) Variegated light grey to yellow micaceous sandy-clayey silt, with rock fragments; (2) Variegated micaceous yellow to grey sandy-clayey silt; (3) Variegated grey sandy-clayey silt; (4) Grey fine to coarse sand, with silt; (5) Dark grey sandy-clayey silt; (6) Dark grey silty fine sand; (7) Dark grey sandy-clayey silt; (8) Yellowish grey fine to medium sand, with silt; (9) Landfill; (B) Standard Penetration Test (SPT) values; (C) Grain size diameter; (D) Content in $\mathrm{CaCO}_{3}$ of the drilling.

Table 1. Radiocarbon datings of the samples collected in the drilling

\begin{tabular}{|c|c|c|c|c|c|c|c|c|c|}
\hline Beta & $\begin{array}{c}\text { Submitter } \\
\text { no }\end{array}$ & $\begin{array}{l}\text { Corrected } \\
\text { level }(m)\end{array}$ & $\begin{array}{c}\text { (Material): } \\
\text { pretreatment }\end{array}$ & $\delta^{13} C_{\% \mathrm{PDB}}$ & Conventional age & $\begin{array}{l}\text { Median } \\
\text { probability } \\
\text { and (2 } \\
\text { sigma } \\
\text { calibration) }\end{array}$ & $\begin{array}{c}\text { Percent } \\
\text { Modern } \\
\text { Carbon } \\
\text { (pMC) }\end{array}$ & $\begin{array}{l}\text { Fraction } \\
\text { Modern }\end{array}$ & $\Delta 14 C$ \\
\hline 455953 & SP02_15 & -7 & $\begin{array}{c}\text { (organic } \\
\text { sediment): acid } \\
\text { washes }\end{array}$ & -24.5 & $36,350 \pm 280 \mathrm{BP}$ & $\begin{array}{c}\text { cal BP } \\
40,950 \text { (cal } \\
\text { BP 41,530- } \\
40,300)\end{array}$ & $\begin{array}{c}1.1 \pm 0.0 \\
\mathrm{pMC}\end{array}$ & $\begin{array}{c}0.0108 \pm \\
0.0004\end{array}$ & $\begin{array}{c}-989.2+/- \\
0.4 \% 0\end{array}$ \\
\hline 444760 & SP02_27 & -19 & $\begin{array}{c}\text { (organic } \\
\text { sediment): acid } \\
\text { washes }\end{array}$ & -24.4 & $41,480 \pm 370 \mathrm{BP}$ & $\begin{array}{c}\text { Cal BP } \\
44,890 \text { (cal } \\
\text { BP 45,580- } \\
4,4200)\end{array}$ & $\begin{array}{c}0.6 \pm 0.1 \\
\mathrm{pMC}\end{array}$ & $\begin{array}{c}0.0057 \pm \\
0.0003\end{array}$ & $\begin{array}{c}-994.3+/- \\
0.3 \% 0\end{array}$ \\
\hline 444761 & SPO2_48 & -40 & $\begin{array}{c}\text { (organic } \\
\text { sediment): acid } \\
\text { washes }\end{array}$ & -29.6 & $>43,500 \mathrm{BP}$ & & $\begin{array}{l}<0.4 \\
\mathrm{pMC}\end{array}$ & $<0.0044$ & $<-995.6 \%$ \\
\hline
\end{tabular}


This condition changed in the sample -38, and myxohaline sediments are recognized in all of the analyzed samples. A single sample (-14) shows an indication of an inner shelf environment, presenting the more positive values of both $\delta^{13} \mathrm{C}$ and N/C.

The variations of $\ln (\mathrm{Fe} / \mathrm{K})$ indicate oscillations in the input of illite or kaolinite to the depositional environment and can be used as proxies for changes in local and regional weathering (Ziegler et al. 2013, Nace et al. 2014, Simon et al. 2015). A higher level in $\mathrm{K}$ is found in samples -12 and -13 (Fig. 5D).

$\mathrm{Ti} / \mathrm{Al}$ ratios are used as indicators of energy variations due to changes in hydraulic equivalence of these elements (Schmitz 1987, Chen et al. 2013). As a rule, except few samples, located in the basal layers, most of the sediments deposited reveal conditions of low energy (Fig. 5E).

The cluster analysis of the distribution of metals (Fig. 6) reveals the existence of two main groups, which can be associated to the dominant mineralogy. The first group involves $\mathrm{K}, \mathrm{Ba}, \mathrm{Sc}, \mathrm{Al}, \mathrm{Mg}$, and $\mathrm{Sr}$, and can be associated with the dominance of clay minerals. The second group encompasses Fe, Ti, Cr, V, Mn, Cu, Ni and Zn, and corresponds to the elements associated with oxides. Calcium remains isolated since it presents an exclusive biogenic origin. Based on this differentiation, a Metal Ratio (MR) was applied (Fig. 5F)(Eq. 1):

$M R=\frac{\Sigma(K+M a+S c+A l+M g+S r)}{\Sigma(F e+T i+C r+V+M n+C u+N i+Z n)}$

The distribution of the MR along the sedimentary sequence shows a distinct pattern when comparing to the two muddy sequences (Fig. 5F). The basal sequence is richer in metals associated oxides, such as Fe and Ti. On the other hand, elements characteristics of clay minerals (silicates), such as $\mathrm{Al}, \mathrm{K}$, and $\mathrm{Sc}$, are more conspicuous in the intermediate muddy sequence. Worth to note that the "oxide-like" sediments correspond to the terrestrial facies, while the "silicate-like" sediments are associated with the myxohaline environment. It points to the possibility of distinct source rocks or climatic conditions between MIS5e and MIS3.

In their interpretation of the stratigraphy of the Santos coastal plain, Suguio and Martin (1978a) recognize the

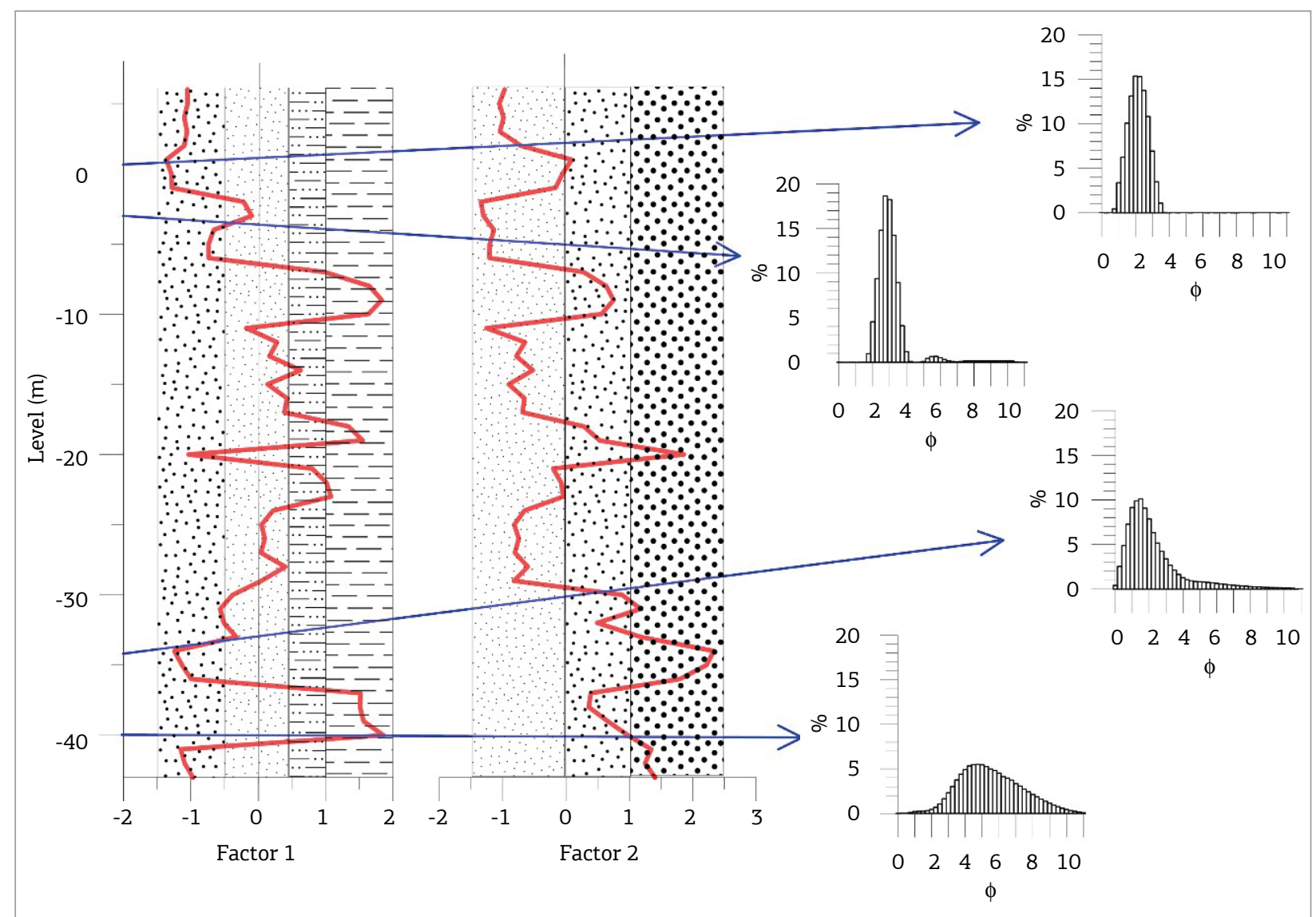

Figure 4. Vertical variations of factors 1 (53.0\% of explained variance) and 2 (34.2\% of explained variance) of the grain size data. Extreme grain size distributions are also shown as histograms. 
A

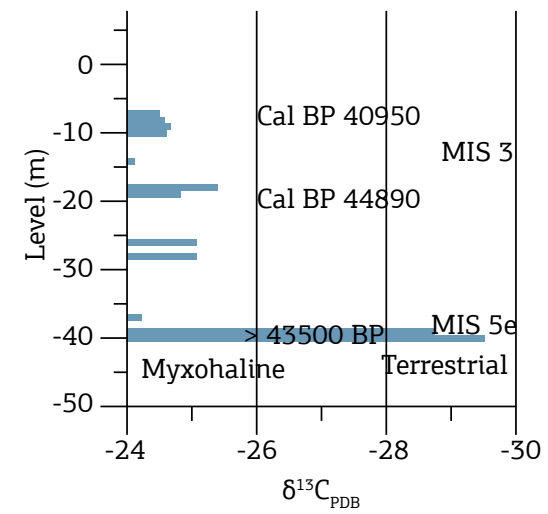

D

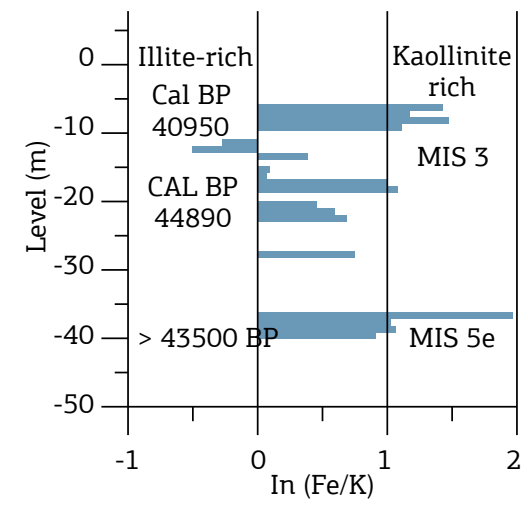

B

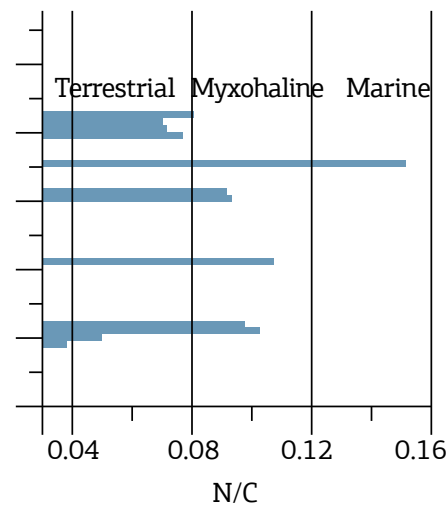

E

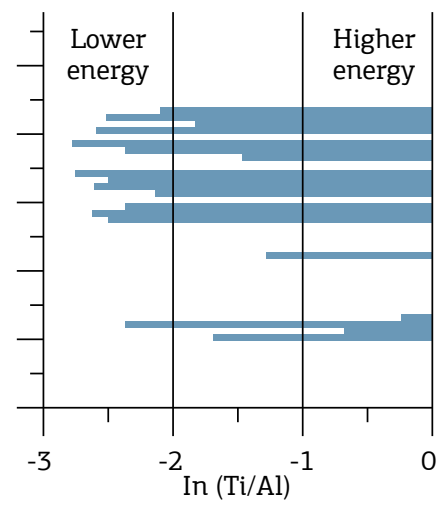

C

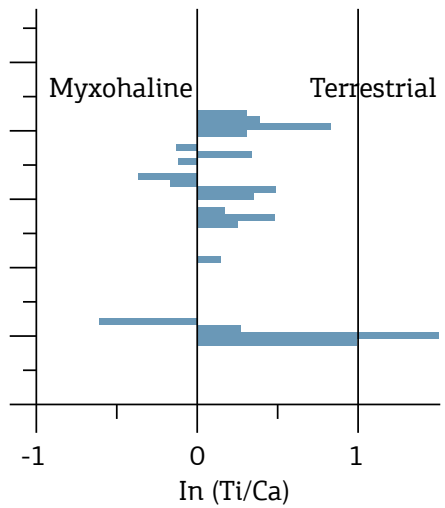

F

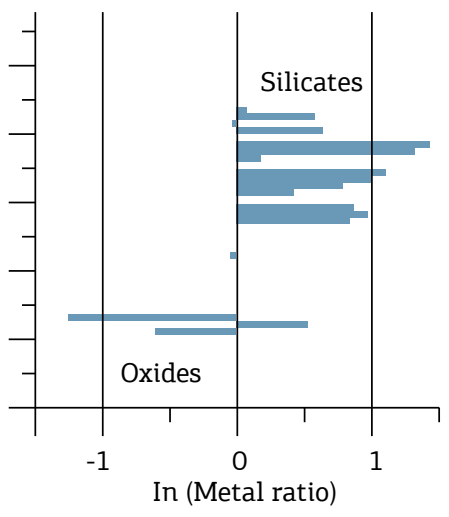

Figure 5. Variations in (A) $\mathrm{d}^{13} \mathrm{C}$; (B) N/C ratio; (C) $\ln (\mathrm{Ti} / \mathrm{Ca})$ along the drilling; (D) $\ln (\mathrm{Fe} / \mathrm{K}) ;(\mathrm{E}) \ln (\mathrm{Ti} / \mathrm{Al}) ;(\mathrm{F}) \ln (\mathrm{Metal}$ ratio) along the drilling.

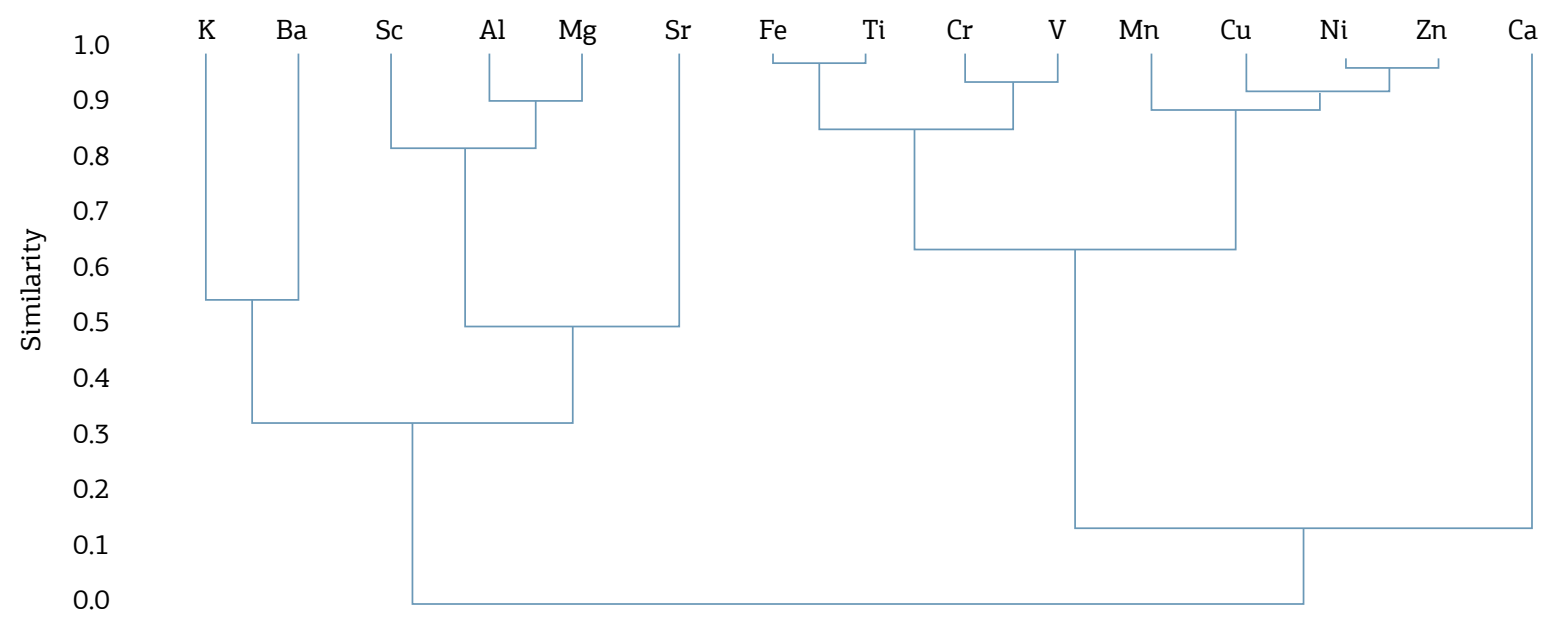

Figure 6. R-mode cluster analysis (Correlation Coefficient, UPGMA clustering) of the metals analysed in this work. 
existence of transitional clays on top of the Late Pleistocene sediments and below the Holocene deposits (layer marked with question marks in Fig. 2), located at depths varying from 5 to $20 \mathrm{mbsl}$. These deposits apparently occupy the distal areas of the plain, in a position that could be associated with the location of the SPT drilling. Therefore, even without recognizing the possibility of an MIS3 transgression, the authors pointed to the occurrence of myxohaline sediments positioned between the MIS5e and Holocene deposits.

In the drilling analyzed here, sediments from the MIS5e lie down directly over weathered rocks of the crystalline basement. The basal sequence corresponds to terrestrial sediments that give place to myxohaline muds, whose age is beyond the limit of the radiocarbon method. Therefore, a fine to very fine sand sequence is deposited, corresponding to the regressive sediments deposited under low sea level. A second muddy layer yielded ages between cal BP 45,000 and 40,000 (MIS3), and all sedimentological and geochemical characteristics point to a myxohaline environment. Between cal BP 43,000 and 42,000 a change in environmental conditions, as indicated by the $\ln (\mathrm{Fe} / \mathrm{K})$ as well as the higher values of $\delta^{13} \mathrm{C}$ and $\mathrm{N} / \mathrm{C}$ ratios, points to a rise in the sea level or to a climatic change, which led to a decrease terrigenous sediment input from the adjacent continental area.

The occurrence of transgressive deposits, associated with the MIS3, at positions above the predicted by the oxygen isotope curves (Chappell \& Shackleton 1986), is reported in several coastal areas. Rodriguez et al. (2000) identified a 15 mbsl deposit, associated with MIS3, on the Texas continental shelf. Also in the United States, Doar III and Kendall (2017) reported MIS3 ages for the 3 mabsl of the Silver Bluff formation, in South Carolina.

In Turkey, a shoreline located at 39-40 mbsl has been dated at 53,000 yr BP, but, in this case, a strong tectonic component cannot be discarded, since the area is located between the African-Arabian and Eurasian plates (Doğan et al. 2012).

In Southeast Asia, coastal deposits, dated between 40,000 and 49,000 $\mathrm{yr} \mathrm{BP}$, located around $20 \mathrm{mbsl}$, also indicate the occurrence of a possible transgressive event during MIS3 (Zhao et al. 2008). A differential tectonic regime was proposed to explain the occurrence of shallow MIS3 deposits in the Changjiang Delta (China). Nevertheless, the MIS3 deposits would remain at depths of about $10 \mathrm{mbsl}$ if the effect of tectonic is removed (Zhao et al. 2008).

Also in Southeast Asia, Hanebuth et al. (2006) recognized the possibility of occurrence of an MIS3 highstand in the region of the River Delta, Vietnam.

In Southeast Brazil, the papers by Mahiques et al. (2011) and Silva et al. (2014) are the first published references that point to the occurrence of MIS3 transgression, represented by myxohaline/lagoonal deposits, located close to the present sea-level.

Close to the area of study, Mahiques et al. (2011) describes a full transition from myxohaline to terrestrial environments, based on radiocarbon datings of foraminifera and organic matter, from ca 39,000 to 24,000 yr BP in a core collected in the São Sebastião Channel, state of São Paulo.

Silva et al. (2014) describe the formation of a sandy barrier, dated on 45,000 yr BP, deposited over lagoonal sediments, presenting ages from 48,000 and 45,000 yr BP, at Maricá region, Rio de Janeiro.

When gathering the information obtained by Mahiques et al. (2011), Silva et al. (2014) and this work, a picture emerges (Fig. 7). It does not correspond to a sea-level curve for the period between cal BP 50,000 and 40,000, but to the position, relative to present sea level, of myxohaline environments, suggesting a trend of sea-level rise in the period. It is important to note that other geological events, such as Late Quaternary crustal movements (Riccomini et al. 1989, Riccomini \& Assumpção 1999, Walker et al. 2016), should be considered in the case of an evaluation of the sea-level curves for the region.

Our findings are in agreement with the conclusions of short-term climatic oscillations which occurred in the first half of the MIS3 (Siddall et al. 2008, Frigola et al. 2012). The transgression here reported can be associated with a sealevel rise phase recorded between events Heinrich HE4 and HE5 (Arz et al. 2007, González \& Dupont 2009).

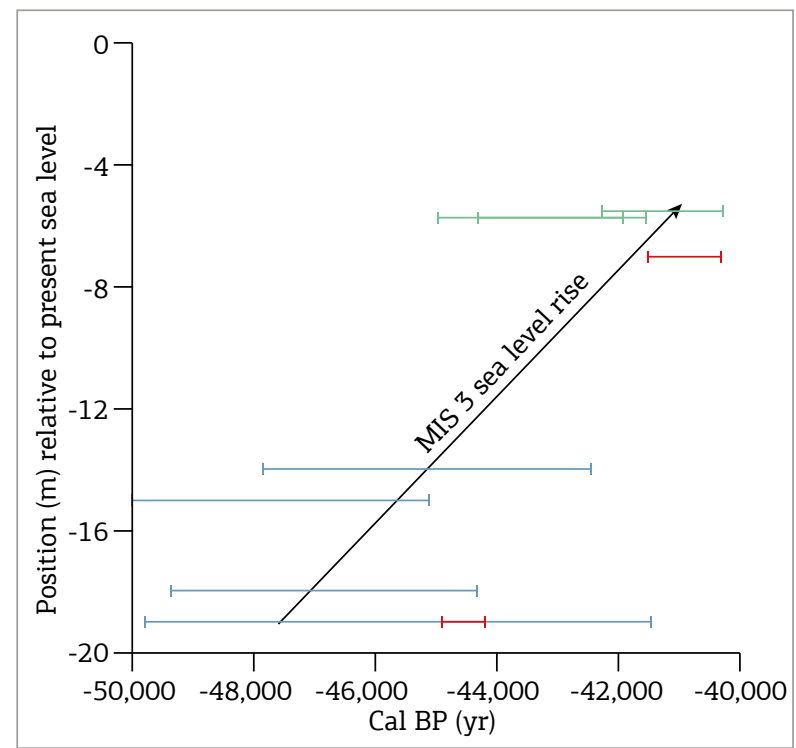

Figure 7. Scatter plot of datings of myxohaline sediments along depths. Data source are Mahiques et al. (2011) (green); Silva et al. (2014) (blue); and this work (red). 


\section{CONCLUSIONS}

Radiocarbon ages, as well as organic and inorganic proxies, have been used to discriminate the MIS3 transgression of the Baixada Santista (SE Brazil) coastal plain, from an older (MIS5e) transgressive event.

The data indicate that, between cal BP 45,600 and 40,300, a myxohaline environment developed at levels between 7 and $19 \mathrm{~m}$ below the present sea level. Also, geochemical proxies suggest a marine transgression (or a climatic change) between cal BP 43,000 and 42,000.

Different metal ratios between the two muddy sequences point to distinct characteristics of the terrestrial versus myxohaline environments, associated with source rocks or climatic conditions.

Previous works, performed on the northern coast of the state of São Paulo as well as on the Rio de Janeiro coastal region (southeast Brazil), corroborate our results and point to the need for a revision of the Late Quaternary sea-level curves in the SW Atlantic coast, as well as of the southeastern Brazilian coastal plains.

Our findings agree with one of the short-term climatic oscillations that occurred in the first half of MIS3.

\section{ACKNOWLEDGMENTS}

The authors are indebted to the Oceanographic Institute of the University of São Paulo, for the infrastructure. Michel M. de Mahiques acknowledges the Conselho Nacional de Desenvolvimento Científico e Tecnológico (CNPq), for the research grant no. 303132/2014-0.

This paper is a contribution to the NAP-Geosedex Project, funded by the University of São Paulo.

\section{REFERENCES}

Almeida F.F.M. \& Carneiro C.D.R. 1998. Origem e evolução da Serra do Mar. Revista Brasileira de Geociências, 28(2):135-150.

Angulo R.J., Lessa G.C., Souza M.C. 2006. A critical review of midto late-Holocene sea-level fluctuations on the eastern Brazilian coastline. Quaternary Science Reviews, 25(5-6):486-506. doi: 10.1016/j.quascirev.2005.03.008

Arz H.W., Lamy F., Ganopolski A., Nowaczyk N., Pätzold J. 2007. Dominant Northern Hemisphere climate control over millennialscale glacial sea-level variability. Quaternary Science Reviews, 26(34):312-321. doi:10.1016/j.quascirev.2006.07.016

Blott S.J. \& Pye K. 2001. GRADISTAT: A grain size distribution and statistics package for the analysis of unconsolidated sediments. Earth Surface Processes and Landforms, 26(11):1237-1248. doi: 10.1002/esp.261.

Cann J.H., Belperio A.P., Gostin V.A., Rice R.L. 1993. Contemporary benthic foraminifera in Gulf St Vincent, South Australia, and a refined Late Pleistocene sea-level history. Australian Journal of Earth Sciences, 40(2):197-211. doi: 10.1080/08120099308728074.

Chappell J. 2002. Sea level changes forced ice breakouts in the Last Glacial cycle: New results from coral terraces. Quaternary Science Reviews, 21(10):1229-1240. doi: 10.1016/s0277-3791(01)00141-x.

Chappell J. \& Shackleton N.J. 1986. Oxygen isotopes and sea level. Nature, 324:137-140. doi: 10.1038/324137a0.

Chen H-F., Yeh P-Y., Song S-R., Hsu S-C., Yang T-N., Wang Y., Chi Z., Lee T-Q., Chen M-T., Cheng C-L., Zou J., Chang Y-P. 2013. The Ti/Al molar ratio as a new proxy for tracing sediment transportation processes and its application in aeolian events and sea level change in East Asia. Journal of Asian Earth Sciences, 73:31-38. doi: 10.1016/j.jseaes.2013.04.017.

Coelho M.R., Martins V.M., Vidal-Torrado P., Souza C.R.G, Perez X.L.O., Vásquez F.M. 2010. Relação solo-relevo-substrato geológico nas restingas da planície costeira do estado de São Paulo. Revista Brasileira de Ciências do Solo, 34(3):833-846.

Corrêa I.C.S. 1996. Les variations du niveau de la mer durant les derniers 17.500 ans BP: l'exemple de la plate-forme continentale du Rio Grande do Sul-Brésil. Marine Geology, 130(1-2):163-178. doi: 10.1016/0025-3227(95)00126-3.
Mahiques M.M., Hanebuth T.J.J., Nagai R.H., Bícego M.C., Figueira R.C.L., Sousa S.H.M., Burone L., Franco-Fraguas P., Taniguchi S. Salaroli A.B., Dias G.P., Prates D.M., Freitas M.E.F. 2017. Inorganic and organic geochemical fingerprinting of sediment sources and ocean circulation on a complex continental margin (São Paulo Bight, Brazil). Ocean Science, 13:209-222. doi: 10.5194/os-13-209-2017.

Mahiques M.M., Sousa S.H.M., Burone L., Nagai R.H., Silveira I.C.A., Figueira R.C.L, Soutelino R.G., Ponsoni L., Klein D.A. 2011. Radiocarbon geochronology of the sediments of the São Paulo Bight (southern Brazilian upper margin). Anais da Academia Brasileira de Ciências, 83(3):817-834. doi: 10.1590/S0001-37652011005000028.

Doar III W.R., Kendall C.G.S.C. 2017. An analysis and comparison of observed Pleistocene South Carolina (USA) shoreline elevations with predicted elevations derived from Marine Oxygen Isotope Stages. Quaternary Research, 82(1):164-174. doi: 10.1016/j.yqres.2014.04.005.

Doğan U., Koçyiğit A., Varol B., Özer İ., Molodkov A., Zöhra E. 2012. MIS 5a and MIS 3 relatively high sea-level stands on the HataySamandağ Coast, Eastern Mediterranean, Turkey. Quaternary International, 262:65-79. doi: 10.1016/j.quaint.2011.12.020.

Dorn R.I., Jull A.J.T., Donahue D.J., Linick T.W., Toolin L.J. 1989. Accelerator mass spectrometry radiocarbon dating of rock varnish. Geological Society of America Bulletin, 101(11):1363-1372. doi: 10.1130/0016-7606(1989)101<1363:amsrdo>2.3.co;2

Frigola J., Canals M., Cacho I., Moreno A., Sierro F.J., Flores J.A., Berné S., Jouet G., Dennielou B., Herrera G., Pasqual C., Grimalt J.O., Galavazi M., Schneider R. 2012. A 500 kyr record of global sea-level oscillations in the Gulf of Lion, Mediterranean Sea: New insights into MIS 3 sea-level variability. Climate of the Past, 8:1067-1077. doi: 10.5194/cp-8-1067-2012.

González C. \& Dupont L.M. 2009. Tropical salt marsh succession as sea-level indicator during Heinrich events. Quaternary Science Reviews, 28(9-10):939-946. doi: 10.1016/j.quascirev.2008.12.023.

Govin A., Holzwarth U., Heslop D., Keeling L.F., Zabel M., Mulitza S., Collins J.A., Chiessi C.M. 2012. Distribution of major elements in Atlantic surface sediments $\left(36^{\circ} \mathrm{N}-49^{\circ} \mathrm{S}\right)$ : Imprint of terrigenous input and continental weathering. Geochemistry, Geophysics, Geosystems, 13(1). doi: 10.1029/2011gc003785. 
Hammer Ø, Harper D.A.T., Ryan P.D. 2001. PAST: Paleontological statistics software package for education and data analysis. Palaeontological Association. Available at: http://palaeo-electronica. org/2001_2001/past/issue2001_2001.htm [cited at Nov. 2016].

Hanebuth T.J.J., Saito Y., Tanabe S., Vu Q.L., Ngo Q.T. 2006. Sea levels during late marine isotope stage 3 (or older?) reported from the Red River delta (northern Vietnam) and adjacent regions. Quaternary International, 145-146:119-134. doi: 10.1016/j.quaint.2005.07.008.

Hogg A.G., Hua Q., Blackwell P.G., Niu M., Buck C.E., Guilderson T.P., Heaton T.J., Palmer J.G., Reimer P.J., Reimer R.W., Turney C.S.M., Zimmerman S.R.H. 2016. SHCal13 Southern Hemisphere Calibration, 0-50,000 Years cal BP. Radiocarbon, 55(4):1889-1903. doi: 10.2458/azu_js_rc.55.16783.

Isla F.I. 1990. Where was the sea-level 30-50,000 years ago'? The Patagonian point of view. Quaternary of South America and Antarctic Peninsula, 6:33-64.

Isla F.I. \& Schnack E.J. 2016. Sea level changes during Marine Isotopic Stage 3 (MIS 3) in Argentina. In: Gasparini G.M., Rabassa J., Deschamps C., Tonni E.P. (eds.) Marine Isotope Stage 3 in Southern South America, 60 KA B.P.-30 KA B.P. Switzerland, Springer International Publishing, p. 147-154.

Lambeck K. \& Bard E. 2000. Sea-level change along the French Mediterranean coast for the past 30000 years. Earth and Planetary Science Letters, 175:203-222.

Murray-Wallace C.V. 2002. Pleistocene coastal stratigraphy, sea-level highstands and neotectonism of the southern Australian passive continental margin - a review. Journal of Quaternary Science, 17(56):469-489. doi: 10.1002/jqs.717.

Murray-Wallace C.V., Belperio A.P., Gostin V.A., Cann J.H. 1993. Amino acid racemization and radiocarbon dating of interstadial marine strata (oxygen isotope stage 3), Gulf St. Vincent, South Australia. Marine Geology, 110(1-2):83-92.

Nace T.E., Baker P.A., Dwyer G.S., Silva C.G., Rigsby C.A., Burns S.J., Giosan L., Otto-Bliesner B., Liu Z., Zhu J. 2014. The role of North Brazil Current transport in the paleoclimate of the Brazilian Nordeste margin and paleoceanography of the western tropical Atlantic during the late Quaternary. Palaeogeography, Palaeoclimatology, Palaeoecology, 415:3-13. doi: 10.1016/j.palaeo.2014.05.030.

NOAA. Bathymetry and global relief. Available at: https://www.ngdc. noaa.gov/mgg/bathymetry/relief.html. [Cited at Oct. 2016].

Pahnke K., Zahn R., Elderfield H., Schulz M. 2003. 340,000-year centennial-scale marine record of Southern Hemisphere climatic oscillation. Science, 301(5635):948-952. doi: 10.1126/science.1084451.

Rabineau M., Berné S., Olivet J-L., Aslanian D., Guillocheau F., Joseph P. 2006. Paleo sea levels reconsidered from direct observation of paleoshoreline position during Glacial Maxima (for the last 500,000 yr). Earth and Planetary Science Letters, 252(1-2):119-137. doi: 10.1016/j.epsl.2006.09.033.

Razik S., Govin A., Chiessi C.M., von Dobeneck T. 2015. Depositional provinces, dispersal, and origin of terrigenous sediments along the SE South American continental margin. Marine Geology, 363:261272. doi: 10.1016/j.margeo.2015.03.001.

Riccomini C. \& Assumpção M. 1999. Quaternary tectonics in Brazil. Episodes, 22:221-225.

Riccomini C., Peloggia A.U.G., Saloni J.C.L., Kohnke M.W., Figueira R.M. 1989. Neotectonic activity in the Serra do Mar rift system (southeastern Brazil). Journal of South American Earth Sciences, 2(2):191-197. doi: 10.1016/0895-9811(89)90046-1.

Rodriguez A.B., Anderson J.B., Banfield L.A., Taviani M., Abdulah K., Snow J.N. 2000. Identification of a $-15 \mathrm{~m}$ Wisconsin shoreline on the Texas inner continental shelf. Palaeogeography, Palaeoclimatology, Palaeoecology, 158(1-2):25-43. doi: 10.1016/s0031-0182(00)00027-4.
Schellmann G. \& Radtke U. 1997. Electron spin resonance (ESR) techniques applied to mollusc shells from South America (Chile, Argentina) and implications for palaeo sea-level curve. Quaternary Science Reviews, 16(3-5):465-475. doi: 10.1016/ s0277-3791(96)00104-7.

Schmitz B. 1987. The $\mathrm{TiO}_{2} \mathrm{Al}_{2} \mathrm{O}_{3}$ ratio in the Cenozoic Bengal Abyssal Fan sediments and its use as a paleostream energy indicator. Marine Geology, 76:195-206. doi: 10.1016/0025-3227(87)90029-6.

Siddall M., Rohling E.J., Thompson W.G., Waelbroeck C. 2008. Marine isotope stage 3 sea level fluctuations: Data synthesis and new outlook. Reviews of Geophysics, 46(4). doi: 10.1029/2007rg000226.

Silva A.L.C., Silva M.A.M., Gambôa L.A.P., Rodrigues A.R. 2014. Sedimentary architecture and depositional evolution of the Quaternary coastal plain of Maricá, Rio de Janeiro, Brazil. Brazilian Journal of Geology, 44(2):191-206. doi: 10.5327/ z2317-4889201400020002.

Simms A.R., DeWitt R., Rodriguez A.B., Lambeck K., Anderson J.B. 2009. Revisiting marine isotope stage 3 and 5a (MIS3-5a) sea levels within the northwestern Gulf of Mexico. Global and Planetary Change, 66(1-2):100-111. doi: 10.1016/j.gloplacha.2008.03.014.

Simon M.H., Ziegler M., Bosmans J., Barker S., Reason C.J., Hall I.R. 2015. Eastern South African hydroclimate over the past 270,000 years. Scientific Reports, 5:18153. doi: 10.1038/srep18153.

Souza M.C. 2005. Estratigrafia e evolução das barreiras holocênicas paranaenses, sul do Brasil. In: Curitiba, Federal University of Paraná, p. 95.

Suguio K. \& Martin L. 1978a. Formações quaternárias marinhas do litoral paulista e sul-fluminense. São Paulo, Instituto de Geociências USP, Sociedade Brasileira de Geologia.

Suguio K. \& Martin L. 1978b. Quaternary marine formations of the State of São Paulo and southern Rio de Janeiro. In: Geologia SBd (ed.) International Symposium on Coastal Evolution in the Quaternary, São Paulo. Sociedade Brasileira de Geologia, p. 1-55.

Van Meerbeeck C.J., Renssen H., Roche D.M. 2009. How did Marine Isotope Stage 3 and last Glacial Maximum climates differ? - Perspectives from equilibrium simulations. Climate of the Past, 5:33-51.

Veiga F.A. 2005. Processos morfodinâmicos e sedimentológicosna plataforma continental rasa paranaense. In: Curitiba, Federal University of Paraná, p. 193.

Vicalvi M.A., Costa M.P.A., Kowsmann R. 1978. Depressão de Abrolhos: uma paleolaguna holocênica na plataforma continental brasileira. Boletim Técnico da Petrobrás, 21:279-286.

Walker R.T., Telfer M., Kahle R.L., Dee M.W., Kahle B., Schwenninger J.L., Sloan R.A., Watts A.B. 2016. Rapid mantle-driven uplift along the Angolan margin in the late Quaternary. Nature Geoscience, 9:909-914. doi: 10.1038/ngeo2835.

Yim W.W.S. 1999. Radiocarbon dating and the reconstruction of late Quaternary sea-level changes in Hong Kong. Quaternary International, 55(1):77-91. doi: 10.1016/s1040-6182(98)00029-9.

Zhao B., Wang Z., Chen J., Chen Z. 2008. Marine sediment records and relative sea level change during late Pleistocene in the Changjiang delta area and adjacent continental shelf. Quaternary International, 186(1):164-172. doi: 10.1016/j.quaint.2007.08.006.

Ziegler M., Simon M.H., Hall I.R., Barker S., Stringer C., Zahn R. 2013. Development of Middle Stone Age innovation linked to rapid climate change. Nature Communications, 4(1905). doi: 10.1038/ ncomms2897.

Available at www.sbgeo.org.br 